\title{
Diversity of Chrysomelidae (Coleoptera) at a mountain range in the limit of the Eurosiberian region, northwest Spain: species richness and beta diversity
}

\author{
Andrés Baselga \& Francisco Novoa
}

\begin{abstract}
Baselga, A. \& Novoa, F. 2007: Diversity of Chrysomelidae (Coleoptera) at a mountain range in the limit of the Eurosiberian region, northwest Spain: species richness and beta diversity. - Entomol. Fennica 18: 65-73.

Chrysomelidae from the Sierra de Queixa mountains (Galicia, northwest Spain) were sampled, reporting 93 species. The estimated local species richness using several non-parametric estimators and accumulation models varies between 104 and 142 species. To compare the Chrysomelidae fauna from Sierra de Queixa with other Galician assemblages we have assessed beta diversity among inventories and we have tested the differences on the zoogeographic compositions among areas. Sierra de Queixa is grouped with other Galician mountain ranges located in the transition zone between Eurosiberian and Mediterranean regions, and it is characterised by a high proportion of Iberian endemic species, significantly higher than expected. Therefore, Chrysomelidae fauna from Sierra de Queixa represents a unique assemblage of Eurosiberian elements that reached the area due to the climatic conditions and Iberian endemic species that are present in the Iberian mountains due to its historic role as southern refugia during glaciations.
\end{abstract}

A. Baselga. Departamento de Biodiversidad y Biología Evolutiva, Museo Nacional de Ciencias Naturales-CSIC, c/ José Gutiérrez Abascal, 2, 28006 Madrid, Spain; E-mail: baselga@mncn.csic.es

F. Novoa. Departamento de Bioloxía Animal, Facultade de Bioloxía, Universidade de Santiago de Compostela, 15706 Santiago de Compostela, Spain; Email:bapaquit@usc.es

Received 4 May 2005, accepted 2 May 2006

\section{Introduction}

Knowledge about Chrysomelidae (Coleoptera) from Galicia (northwest Spain) has been notably increased in the last years with the study of several local faunas (Baselga \& Novoa 2000a, 2000b, 2002a) and the publication of taxonomic papers (Baselga \& Novoa 2000c, 2002b, 2002c, 2003, 2004). The accumulation of such data have allowed to estimate the regional species richness and thus the completeness of the Galician inven- tory (Baselga \& Novoa 2006) as well as to assess beta diversity among local faunas, including inventories from coastal environments to mountain ranges (Baselga \& Novoa 2005). In this scope, we study here the leaf beetle fauna from Sierra de Queixa (Ourense, Spain) (Fig. 1), an area included in the Eurosiberian phytogeographic region (Izco 1987, Rivas-Martínez 1987) but adjacent to the limit of the Mediterranean region, searching for the unrecorded taxa that were predicted to be present in Galicia by several estima- 

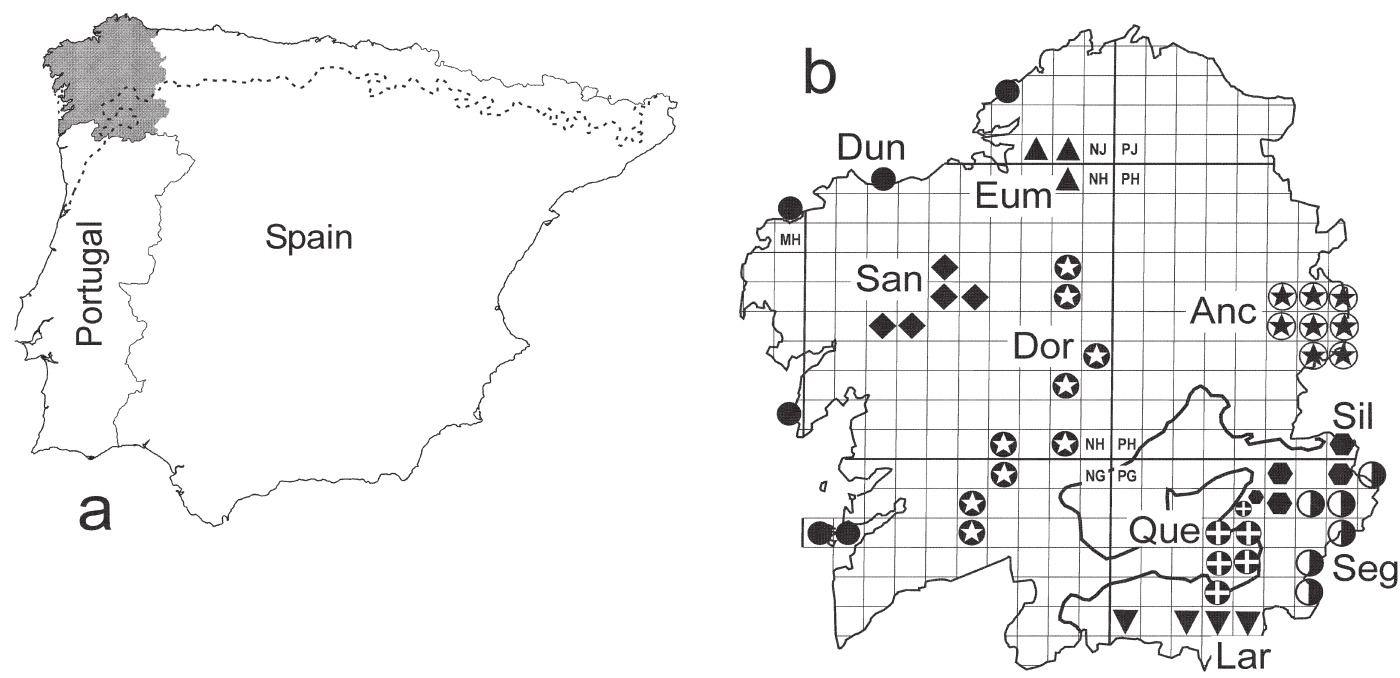

Fig. 1. Location of the studied area in Galicia, northwest of the Iberian peninsula. - a. Galicia (shadowed) is located in the boundary between Eurosiberian and Mediterranean phytogeographic regions (discontinuous line, after Rivas-Martínez 1987). - b. Location of Sierra de Queixa (Que) and other areas selected for the analysis of beta diversity. The squared pattern corresponds to the $10 \mathrm{~km}$ UTM grid (zone 29T, $100 \mathrm{~km}$ squares MH, NG, NH, NJ, PG, PH and PJ) and the continuous line is the boundary between phytogeographic regions (Izco 1987, Rivas-Martínez 1987). Each inventory is composed of several localities marked with the same symbol. See Materials and Methods for further explanation.

tion methods (Baselga \& Novoa 2006) and surveying a new area in order to improve the description of turnover patterns among Galician local faunas (Baselga \& Novoa 2005). Our study was the first extensive one in Sierra de Queixa.

The aims of this paper are (i) to describe the local species richness of this highly diverse group, (ii) to estimate the completeness of the inventory, assessing the accumulation curve generated from our sampling, and (iii) to compare this fauna with other Galician ones, analysing beta diversity among inventories and its differences in the proportions of chorotypes contributing to each local fauna.

\section{Material and methods}

Sierra de Queixa forms part of the Galician Macizo Central, a group of mountain ranges with summits up to $1,700 \mathrm{~m}$ located in the Spanish province of Ourense (Galicia). The range is included in the Eurosiberian phytogeographic region (Izco 1987, Rivas-Martínez 1987) but Sierra de Queixa is adjacent to the temperate valleys of Sil and Bibei rivers, both belonging to the Medi- terranean region. Therefore, in this area there is a high turnover, with Eurosiberian vegetation replacing Mediterranean one in a small extent.

An extensive sampling in Sierra de Queixa was carried out by authors in 2002 and 2003, though some previous captures are also considered in this paper. Twenty localities were surveyed (Fig. 1). They were selected in order to range the entire altitudinal gradient and the main vegetation units. A total of 789 specimens were collected by sweeping and beating the vegetation. Samplings were not standardized, and we collected all the species detected in each locality but not all the specimens of each species. All the material is deposited in A. Baselga collection in the Departamento de Biología Animal, Universidad de Santiago de Compostela, Spain.

To assess the completeness of the inventory both asymptotic models and non-parametric estimators (ICE, Chao 2 and jackknife of first order and second) were used (Colwell \& Coddington 1994). We used only incidence-based estimators since not all the specimens sawn were collected in each sampling and thus no abundance measures are available. Among them, we selected those recommended be Hortal et al. (2006). The accu- 
mulation curves and the non-parametric estimators were generated with EstimateS 7.0 software (Colwell 2004), randomising the sample order 100 times. Database records (Soberón et al. 2000, Hortal et al. 2001, Martín-Piera \& Lobo 2003) and individuals were used as a sampling-effort surrogate. Our database comprised 270 records for 789 specimens. Each record is composed of the following fields: species name, locality, date, number of specimens and collector. Any difference in any database field value gives rise to a new database record, so increments of the number of records provide correlative increments of the sampling effort (Martín-Piera \& Lobo 2003). Thereafter, the asymptotic Clench function was fitted to the smoothed curve (Soberón \& Llorente 1993, Hortal et al. 2004, Jiménez-Valverde et al. 2006):

$S_{(e)}=\mathrm{a} e /(1+\mathrm{b} e)$

where $S_{(e)}$ is the number of species found per sampling effort unit $e$; a and $\mathrm{b}$, the parameters of the function. These latter parameters were adjusted to the data of the curve by means of a Simplex and Quasi Newton method (StatSoft 2001). The asymptote (i.e. the predicted number of species) is calculated as a/b.

For the comparison of the present inventory with other Galician faunas we have considered the previously published data (Baselga \& Novoa 2006), taking into account all the available inventories: coastal dunes and associated marshes (Dun), agricultural landscape near Santiago de Compostela (San), Atlantic mixed forest of low altitude in Fragas del Eume Natural Park (Eum), medium altitude mountain ranges of Dorsal Gallega (Dor) and Larouco (Lar), the temperate valley of the Sil river (Sil) and high mountain ranges of Ancares (Anc) and Eixo-Segundera (Seg). The present inventory is abbreviated as Que for tables and figures. Simpson's index $\left(\beta_{\text {sim }}\right)$ was used as beta diversity measure (Koleff et al. 2003):

$\beta_{\text {sim }}=\min (b, c) / \min (b, c)+a$

where $a$ is the total number of species that occur in both areas, $b$ is the total number of species that occur in the first area but not in the second, and $c$ is the total number of species that occur in the second area but not in the first. This index was selected because it focuses on compositional differences independent of species richness gradients, and thus it is a 'narrow sense' measure of turnover (Koleff et al. 2003). A distance matrix was constructed with $\beta_{\text {sim }}$ for each pair of faunas, and thereafter used in a a nonmetric multidimensional scaling (NMDS) (Legendre \& Legendre 1998), generated with Statistica 6.0 (StatSoft 2001). Three dimensions were considered because the screeplot showed a small change of the stress values with dimensionality increments after this point (Legendre \& Legendre 1998) (stress = $0.0552)$. Thereafter, the matrix for these three dimensions versus the nine inventories was used in a cluster analysis, in order to recover the major groups of local faunas. The tree was constructed with Clustan Graphics 6.03 (Clustan 2003), weighting the three variables after the respective decrease of stress explained by each dimension, and then grouping the faunas using Euclidean distance and single linkage.

Biogeographic types used in this paper were synthesized following the chorotypes proposed by Vigna Taglianti et al. (1992) and then grouping them into four major categories: Iberian elements (Ibe), for species endemic from the Iberian Peninsula; Mediterranean elements (Med), for species widespread in the Mediterranean countries; Eurosiberian elements (Eur), for species widespread in Europe, or Europe and the Siberian range; and finally wide range elements (WR), for species widespread in all or a great part of the $\mathrm{Pa}$ laearctic region, and reaching parts of both Eurosiberian and Mediterranean areas. These major divisions are established in order to make clear the contrast between Eurosiberian (septentrional) and Mediterranean (meridional) contributions to Galician fauna which is located across the Eurosiberian-Mediterranean boundary. The other two categories are neutral regarding this aspect, because almost all Iberian elements are present in both sides of Eurosiberian-Mediterranean limit, as well as WR elements reach both regions.

To test the statistical significance of differences on biogeographic patterns among inventories a chi square analysis $\left(\chi^{2}\right)$ was performed. The contingency table was constructed with the four 

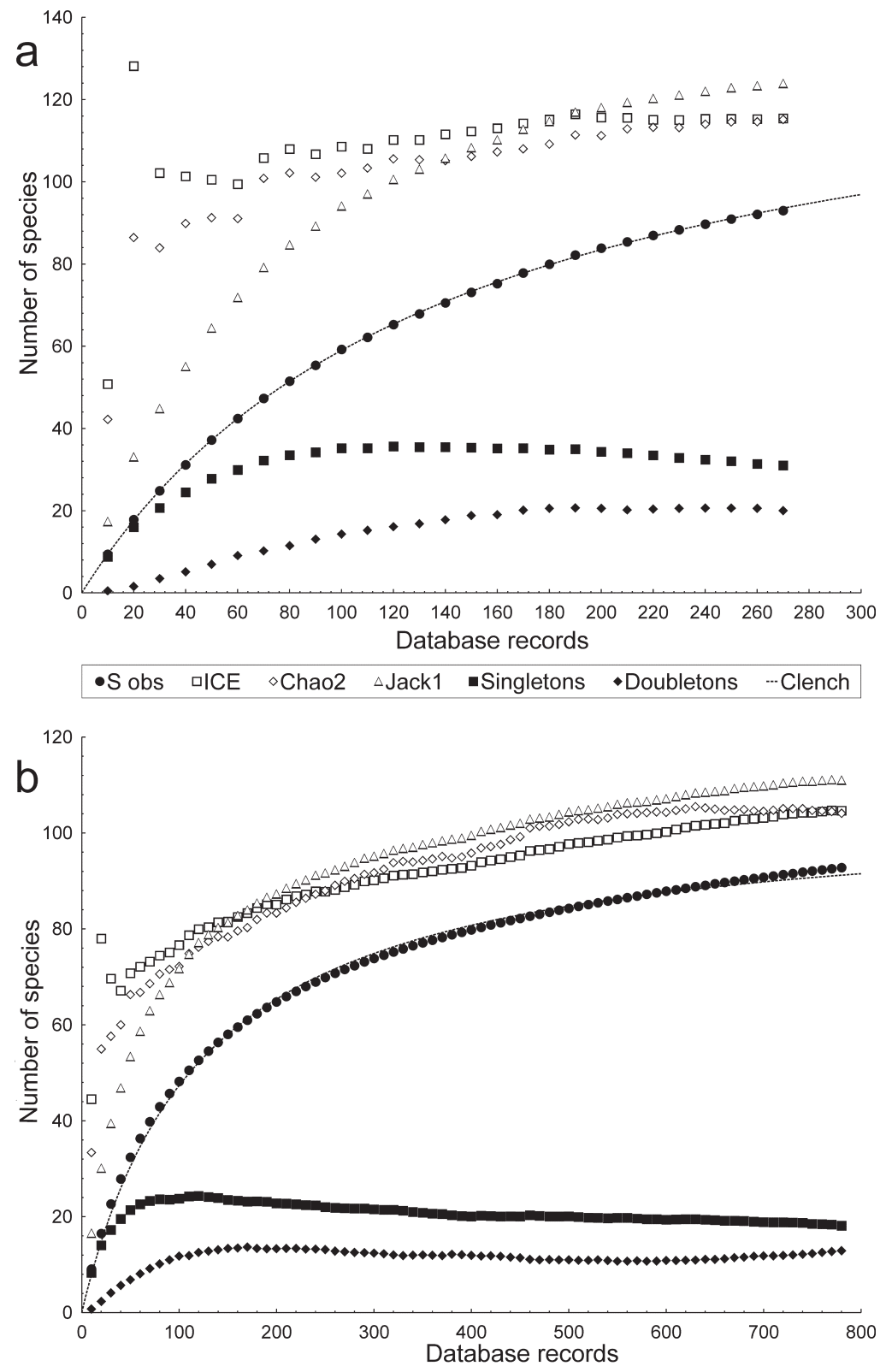

Fig. 2. Species accumulation curves generated from the field study in Sierra de Queixa with the fitted Clench function, the nonparametric estimators ICE, Chao2 and first-order jackknife and the number of singletons and doubletons. - a. Curve based on the accumulation of database records. - b. Curve based on the accumulation of individuals.

biogeographic categories (columns: WR, Eur, Med, Ibe) versus the nine inventories (rows: Dun, San, Eum, Dor, Lar, Sil, Anc, Seg and Que). Probability considered to reject the null hypothesis (differences are due to random chance) is $95 \%$. The degrees of freedom are 1 for the cells, 3 for the row subtotals, 8 for the column subtotals and 24 for the whole contingency table, and the critical $\chi^{2}$ values $3.8415,7.8147,15.5073$, 36.4150 respectively

\section{Results}

A total of 93 species of Chrysomelidae have been collected in Sierra de Queixa. The full list of species and exact sampling localities are available from the authors on request. The leaf beetle fauna in Sierra de Queixa is mostly composed of WR elements (43.0\%). The proportions of Eur and Med elements are equal (16.1\%), and the Ibe endemisms reach near a quarter of the inventory 
Table 1. Estimated species richness using database records and individuals as sampling effort surrogate.

\begin{tabular}{lcc}
\hline Estimate & Records curve & Individuals curve \\
\hline Clench & 142 & 105 \\
ICE & 115 & 105 \\
Chao 2 & 115 & 104 \\
Jacknife 1 & 124 & 111 \\
Jacknife 2 & 135 & 116 \\
\hline
\end{tabular}

(24.7\%). Among the cited taxa, 6 species are specially interesting: Psylliodes cervinoi Baselga \& Novoa is firstly recorded here since its description from Sierra Segundera (Baselga \& Novoa 2003), extending its known distribution to Queixa mountain range, whereas Stylosomus minutissimus (Germar, 1823), Pachybrachis suffriani Schauffus, 1862, Galeruca interrupta (Illiger, 1802), Luperus longicornis (Fabricius, 1781) and Psylliodes obscuroaeneus Rosenhauer, 1856 are new records for Galicia, increasing the regional inventory from 276 to 281 species.

The completeness of the present inventory was evaluated by means of accumulation models and several non-parametric estimators, using both database records and individuals as sampling effort surrogates (Fig. 2). Our results show that a total richness between 104 and 142 species could be expected in the studied area, depending on the curve assessed and the estimator selected (Table 1). Therefore between $65 \%$ and $90 \%$ of the estimated number of species of Chrysomelidae living in Sierra de Queixa seems to be detected in our field study, but we should expect that between 12 and 49 taxa will be added to this inventory in the future. Moreover, in both curves the slope at the end of the survey is quite low: 0.1195 using records and 0.0156 using individuals. These values imply that more than 8 records or 64 individuals should be added to the inventory, and thus the completeness of the inventory is quite high (Jiménez-Valverde \& Hortal 2003, Hortal et al. 2004).

To compare the leaf beetle fauna from Sierra de Queixa with those of other Galician areas we have assessed beta diversity among inventories, considering the presence data reported in Baselga and Novoa (2006). The NMDS (Fig. 3a) was performed with three dimensions $($ stress $=0.0552$ )
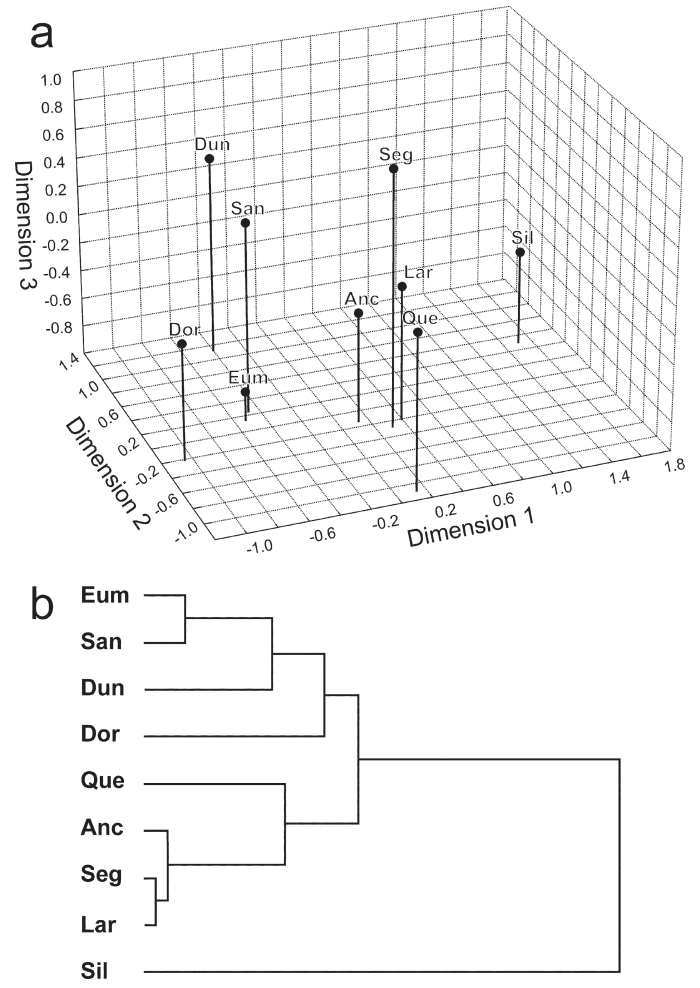

Fig. 3. Comparison of leaf beetles from Sierra de Queixa with other Galician local faunas. - a. Nonmetric multidimensional scaling (NMDS) based on Simpson's measure of beta diversity (stress $=$ 0.0552). - b. Dendrogram from the cluster analysis, constructed after the matrix for faunas vs. dimensions produced by the NMDS. Euclidean distance and single linkage were used.

because the screeplot showed a small change of the stress values with dimensionality increments after this point (Legendre \& Legendre 1998). Major groups of Galician faunas were recovered by a cluster analysis, using the matrix for faunas vs. dimensions produced by the NMDS. The dendrogram constructed from this matrix shows three major faunistic groups (Fig. 3b). The leaf beetle fauna from Sierra de Queixa is grouped with those of other mountain ranges which are located in the trasition zone between Eurosiberian and Mediterranean regions (Ancares, Larouco and Eixo-Segundera). The other two clusters were also found elsewhere (Baselga \& Novoa 2005): on one hand, the low and medium altitude areas closer to the Atlantic coast (coastal dunes, Santiago, Eume Natural Park and Dorsal Gallega) and, 
Table 2. Contingency table for the biogeographic patterns versus the local inventories. Significant differences are noted in bold face. Observed and expected values are noted as $(O)$ and $(E)$, respectively. $\chi^{2}$ total value for the whole table $=49.19$.

\begin{tabular}{|c|c|c|c|c|c|c|c|c|c|c|}
\hline Corotype & WR & WR $\chi^{2}$ & Eur & Eur $\chi^{2}$ & Med & $\operatorname{Med} \chi^{2}$ & Ibe & Ibe $\chi^{2}$ & $\begin{array}{l}\text { Sub- } \\
\text { total }\end{array}$ & Subt. $\chi^{2}$ \\
\hline Dun (O) & 72 & & 11 & & 22 & & 8 & & 113 & \\
\hline Dun (E) & 59.5 & 2.6 & 18.2 & 2.9 & 18.5 & 0.7 & 16.8 & 4.6 & & 10.8 \\
\hline $\operatorname{San}(\mathrm{O})$ & 66 & & 16 & & 10 & & 12 & & 104 & \\
\hline San (E) & 54.7 & 2.3 & 16.8 & 0.0 & 17.0 & 2.9 & 15.5 & 0.8 & & 6.0 \\
\hline Eum (O) & 43 & & 18 & & 9 & & 17 & & 87 & \\
\hline Eum (E) & 45.8 & 0.2 & 14.0 & 1.1 & 14.2 & 1.9 & 12.9 & 1.3 & & 4.5 \\
\hline Dor (O) & 45 & & 14 & & 13 & & 11 & & 83 & \\
\hline Dor (E) & 43.7 & 0.0 & 13.4 & 0.0 & 13.6 & 0.0 & 12.4 & 0.2 & & 0.2 \\
\hline Lar (O) & 40 & & 11 & & 12 & & 10 & & 73 & \\
\hline Lar (E) & 38.4 & 0.1 & 11.8 & 0.1 & 11.9 & 0.0 & 10.9 & 0.1 & & 0.2 \\
\hline Sil (O) & 50 & & 10 & & 30 & & 13 & & 103 & \\
\hline Sil (E) & 54.2 & 0.3 & 16.6 & 2.6 & 16.9 & 10.3 & 15.3 & 0.4 & & 13.6 \\
\hline Anc $(O)$ & 69 & & 31 & & 20 & & 21 & & 141 & \\
\hline Anc (E) & 74.2 & 0.4 & 22.8 & 3.0 & 23.1 & 0.4 & 21.0 & 0.0 & & 3.8 \\
\hline $\operatorname{Seg}(\mathrm{O})$ & 35 & & 15 & & 12 & & 15 & & 77 & \\
\hline Seg $(E)$ & 40.5 & 0.8 & 12.4 & 0.5 & 12.6 & 0.0 & 11.5 & 1.1 & & 2.4 \\
\hline Que (O) & 40 & & 15 & & 15 & & 23 & & 93 & \\
\hline Que (E) & 49.0 & 1.6 & 15.0 & 0.0 & 15.2 & 0.0 & 13.8 & 6.1 & & 7.7 \\
\hline Subt. (O) & 460 & 8.31 & 141 & 10.26 & 143 & 16.2 & 130 & 14.4 & 874 & 49.2 \\
\hline
\end{tabular}

on the other, the fauna from the Sil Valley that is the most different one.

The comparison of the biogeographic compositions of the local inventories shows similar results (Table 2). The column subtotal $\chi^{2}$ for Sierra de Queixa is quite high (close to the critical value but not significant at $p<0.05$ ) almost completely due to the large proportion of Iberian endemics, which is significantly higher than expected by chance. Only two inventories are significantly different to the others: Sil valley, due especially to its high proportion of Mediterranean elements and coastal dunes due mainly to its small percentage of Iberian endemisms. These disparities produce a high total $\chi^{2}$ value for the whole table, implying significant differences among the compared faunas.

\section{Discussion}

Chrysomelidae constitute an interesting group to develop biodiversity estimates due to two main reasons: on the one hand it is a hyperdiverse family and, on other, they provide a good representa- tion of the free living phytophagous functional group within arthropods. The study of leaf beetles from Sierra de Queixa has revealed a very interesting local fauna, quite singular among the regional assemblages due to the striking high proportion of Iberian endemics (24.7\%) (Fig. 4, Table 2) or the citation of several taxa new for Galicia. The addition of five new species to the regional inventory may be considered valuable, since completeness of Galician Chrysomelidae list was already very high, between 85 and 95\% of the estimated richness (Baselga \& Novoa 2006). This saturation is more difficult to get at a smaller scale because of the great number of samplings that would be required for each local area, and thus a degree of completeness between 65 and $90 \%$ may be considered acceptable, considering that we are working with a highly diverse group of invertebrates. Therefore, further sampling effort in Sierra de Queixa would add new taxa to the inventory (between 12 and 49 taxa after our estimates) but current knowledge of Queixa leaf beetles is already suitable in order to describe the local assemblage and the regional biodiversity patterns. Comparing the different es- 


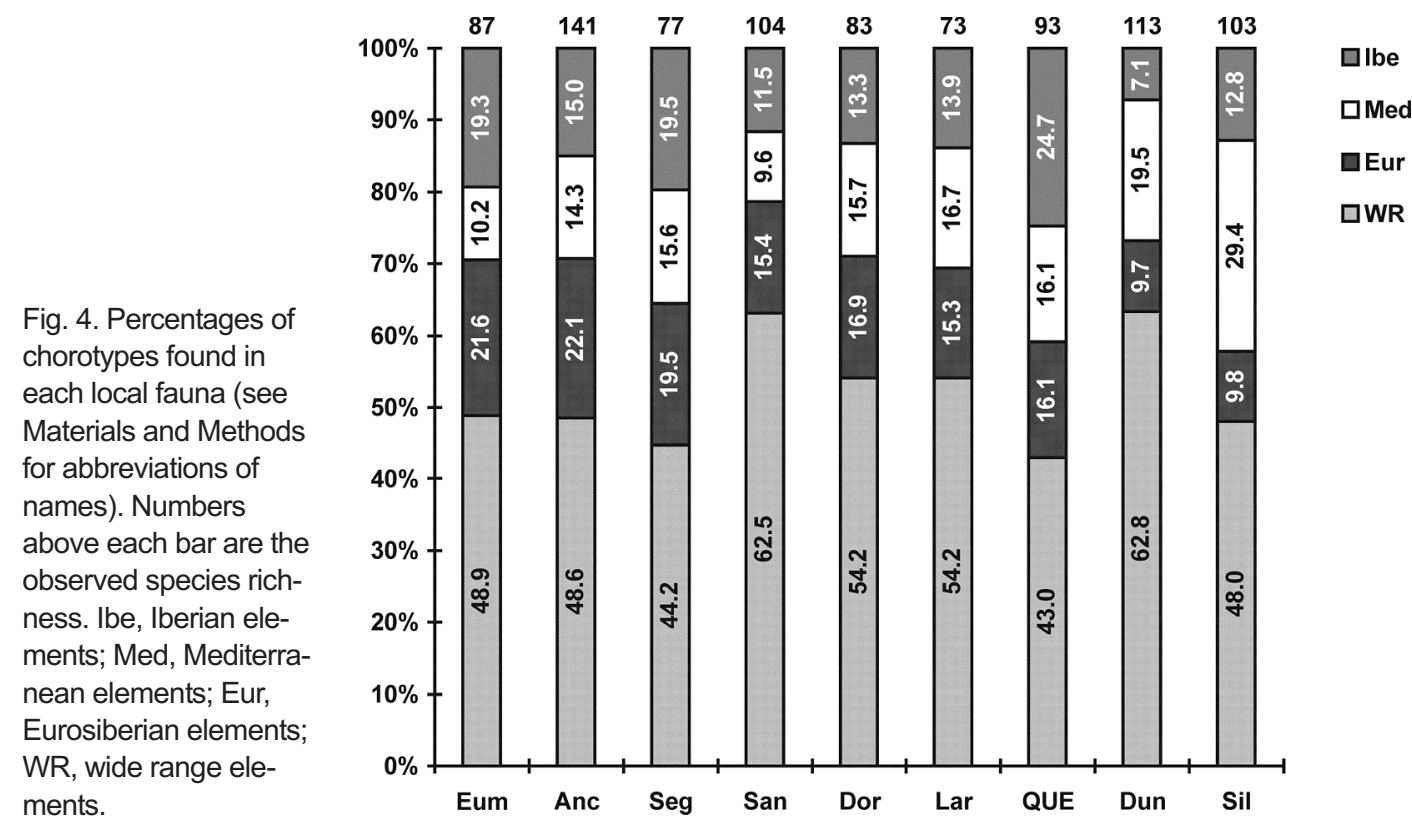

timates (Table 1), the maximum value is recovered adjusting the Clench function to the accumulation curve using database records as sampling effort surrogate (142), whereas the minimum one is provided by the Chao 2 estimator in the individuals curve (104). In all cases, estimates of the curve based on individuals are lower than those yielded by the curve based on records, but the difference between the Clench asymptotes of both curves is the most remarkable discrepancy. Examination of the frequency of records per species in the curve based on records shows an important number of species with 4 or less records (not shown). This causes the curve to overestimate total species number. Such drawback is less important when using individuals. In this curve, values of Clench asymptote and non-parametric estimators are more similar. More research on the behaviour of species accumulation curves is needed, because in our data set the number of singletons and doubletons is considerable, so nonparametric estimators should be overestimating the richness value, and thus it is striking that asymptotic model yield grater values, contrary to the results found by Hortal et al. (2006).

When the Chrysomelidae fauna from Sierra de Queixa is compared with other Galician inventories analysing beta diversity and ordering localities by means of a NMDS, three major groups are found. Queixa is grouped together with other mountain ranges located in both sides of the Eurosiberian-Mediterranean phytogeographic boundary (Izco 1987, Rivas-Martínez 1987). This group was previously recovered in similar comparison performed without including present data (Baselga \& Novoa 2005) and the addition of Queixa inventory to this cluster is not surprising taking into account its location. The conclusion that faunistic isolation of Sil Valley (Figs. 3 and 4) is due to environmental factors (i. e. temperature, pluviosity), because no geographical barriers are interposed, is here newly supported. Sierra de Queixa and Sil Valley are strictly contiguous as well as Sil Valley and Eixo-Segundera. Also the clustering of two faunas located in the phytogeographic Mediterranean region (Larouco and Eixo-Segundera) with the Eurosiberian inventories is again corroborated. Hence, it should be emphasized that although the Larouco and EixoSegundera ranges are included into the phytogeographic Mediterranean region together with the Sil Valley, only the latter area has an unambiguous Mediterranean-type Chrysomelidae fauna (Fig. 5). This conclusion was pointed in Baselga \& Novoa (2005) but it is statistically tested here for the first time. The contingency table shows significant differences in the distributions of biogeographic categories among local faunas (Table 
2). In the case of Sil valley Mediterranean elements are significantly higher than expected.

The zoogeographical zonation is different for each group considered, but as a general pattern Eurosiberian faunas occupy areas that RivasMartínez (1987) includes in the Mediterranean region in his classification of Iberian vegetation, a pattern also pointed out by Hermida et al. (1994) for western Iberian gastropods, Rodríguez et al. (1997) for western Iberian earthworms and Hortal-Muñoz et al. (2000) for Portuguese dung beetles. As Williams (1996) comments, the arbitrary "border lines" between biogeographic regions are not realistic representations of the ecological reality, because they can be wider than the grain used for their delimitation. In fact, it seems that more than a sharp boundary, the transitional zone is composed by a mosaic of leaf beetle faunas depending on the local climatic conditions. These environmental variables are mostly determined by the complicated regional geomorphology. Therefore, mountains located south of the boundary (and then included in the Mediterranean region; i.e. Larouco, Eixo-Segundera) host Eurosiberian faunas, whereas temperate valleys located north to the boundary shelter Mediterranean faunas (i.e the Navia valley in Ancares range; Baselga \& Novoa 2000b). This mosaic produces strong gradients and sharp faunal replacements in some places. This is the case of Sierra de Queixa and the contiguous Sil Valley, where the transition from unambiguous Eurosiberian localities in the mountains (close to 1700 masl) to clearly Mediterranean areas in the temperate valleys (at 300 masl) occurs in less than 10 $\mathrm{km}$. Considering that Mediterranean and Iberian endemic species could be relict taxa isolated in Pleistocene refugia during glaciations (see Ribera \& Vogler 2004), the faunistic uniqueness of Sierra de Queixa is based in the confluence of both Eurosiberian taxa (able to attain the mountain range due to current climatic conditions) and relict Iberian species (which are present in the mountain range due to its historic role as southern refuge during glaciations).

In summary, the check-list of Chrysomelidae from Sierra de Queixa has reported interesting faunistic findings as the new record of Psylliodes cervinoi, the citations of new taxa for Galicia or the description of this Iberian endemic-rich fauna, unique among regional assemblages. Moreover, the addition of this study to the regional knowledge has allowed us to reassess leaf beetle beta diversity in the region. The new data support the conclusions reported in our study of the faunistic heterogeneity of Galician leaf beetles (Baselga \& Novoa 2005) and it should be assumed that the described patterns are robust. They show that zoogeographic distribution of Chrysomelidae faunas in northwestern Spain do not fit exactly the standard phytogeographic zonation (Izco 1987, Rivas-Martínez 1987). Only Sil Valley has an unambiguous Mediterraneantype fauna, whereas mountain ranges of Larouco and Eixo-Segundera, though located in the phytogeographic Mediterranean region, are grouped with Eurosiberian leaf beetle faunas.

Acknowledgements. We are grateful to S. Barallobre, I. Gañán, J. Novoa, R. Novoa and M. Santiago for their collaboration on several samplings. We wish to thank two anonymous referees for their interesting suggestions that greatly improved this paper. This research was supported by Xunta de Galicia with project PGIDT01MAM 20001PR.

\section{References}

Baselga, A. \& Novoa, F. 2000a: Los Chrysomelidae (Coleoptera) de los sistemas dunares de Galicia (Noroeste de España). — Boln. R. Soc. Esp. Hist. Nat. (Sec. Bio1.) $96(1-2)$ : $113-124$.

Baselga, A. \& Novoa, F. 2000b: Los Chrysomelidae (Coleoptera) de la Sierra de Ancares, Noroeste de la España (Coleoptera). — Nouv. Rev. Ent. (N. S.) 17(2): 165180.

Baselga, A. \& Novoa, F. 2000c: Cryptocephalus cantabricus Franz, a poorly known endemic species from the northwest of the Iberian Peninsula (Coleoptera: Chrysomelidae). — Koleopt. Rundsch. 70: 191-195.

Baselga, A. \& Novoa, F. 2002a: Los Chrysomelidae (Coleoptera) de las sierras orientales de Ourense (Galicia, noroeste de la Península Ibérica). - Boln. Asoc. esp. Ent. 26(3-4): 57-73.

Baselga, A. \& Novoa, F. 2002b: New species of Aphthona (Coleoptera: Chrysomelidae: Alticinae) and key to Iberian species of Aphthona hammarstroemi group. Can. Entomol. 134(1): 1-7.

Baselga, A. \& Novoa, F. 2002c: Donacia galaica Báguena, 1959, una especie poco conocida del noroeste ibérico (Coleoptera, Chrysomelidae). Nouv. Rev. Ent. (N. S.) 19(3): 229-233.

Baselga, A. \& Novoa, F. 2003: A new species of Psylliodes 
(Coleoptera: Chrysomelidae) and key to the wingless species from the Iberian Peninsula. - Ann. Entomol. Soc. Am. 96(6): 689-692.

Baselga, A. \& Novoa, F. 2004: Larvae of the Gonioctena subgenus Spartoxena: description of mature larvae of G. leprieuri and G. aegrota (Coleoptera: Chrysomelidae: Chrysomelinae). — Can. Entomol. 136(3): 313-321.

Baselga, A. \& Novoa, F. 2005: Faunistic heterogeneity across Eurosiberian-Mediterranean boundary: Chrysomelidae (Coleoptera) in Galicia, Spain. - Ann. Entomol. Soc. Am. 98(4): 558-564.

Baselga, A. \& Novoa, F. 2006: Diversity of Chrysomelidae (Coleoptera) in Galicia, Northwest Spain: estimating the completeness of the regional inventory. Biodivers. Conserv. 15(1): 205-230.

Clustan. 2003: Clustan Graphics computer program, version 6.03. By Clustan, Edinburgh, Scotland.

Colwell, R. K. 2004: EstimateS: Statistical estimation of species richness and shared species from samples. computer program, version 7.0. By Colwell, R. K., Connecticut. Persistent URL http://purl.oclc.org/estimates (downloaded: September 22nd, 2005).

Colwell, R. K. \& Coddington, J. A. 1994: Estimating terrestrial biodiversity through extrapolation. - Phil. Trans. R. Soc. Lond. B 345: 101-118.

Hermida, J., Outeiro, A. \& Rodríguez, T. 1994: Biogeography of Terrestrial Gastropods of North-West Spain. - J. Biogeogr. 21(2): 207-217.

Hortal-Muñoz, J., Martín-Piera, F. \& Lobo, J. M. 2000: Dung beetle geographic diversity variation along a Western Iberian latitudinal transect (Coleoptera: Scarabaeidae). - Ann. Entomol. Soc. Am. 93(2): 235-243.

Hortal, J., Lobo, J. M. \& Martín-Piera, F. 2001: Forecasting insect species richness scores in poorly surveyed territories: the case of the Portuguese dung beetles (Col. Scarabaeinae). — Biodivers. Conserv. 10: 13431367.

Hortal, J., García-Pereira, P. \& García-Barros, E. 2004: Butterfly species richness in mainland Portugal: Predictive models of geographic distribution patterns. Ecography 27: 68-82.

Hortal, J., Borges, P. A. V. \& Gaspar, C. 2006: Evaluating the performance of species richness estimators: sensitivity to sample grain size. - J. Anim. Ecol. 75(1): 274-287.

Izco, J. 1987: Galicia. — In: Peinado-Lorca, M. and S. Rivas-Martínez (eds.), La vegetación de España: 385418. Universidad de Alcalá de Henares, Alcalá de Henares.
Jiménez-Valverde, A., Mendoza, S. J., Cano, J. M. \& Munguira, M. L. 2006: Comparing relative model fit of several species-accumulation functions to local Papilionoidea and Hesperioidea butterfly inventories of Mediterranean habitats. - Biodivers. Conserv. 15(1): 177-190.

Jiménez-Valverde, A. \& Hortal, J. 2003: Las curvas de acumulación de especies y la necesidad de evaluar la calidad de los inventarios biológicos. - Rev. Iber. Aracnol. 8: 151-161.

Koleff, P., Gaston, K. J. \& Lennon, J. K. 2003: Measuring beta diversity for presence-absence data. — J. Anim. Ecol. 72: 367-382.

Legendre, P. \& Legendre, L. 1998: Numerical ecology, 2nd ed. Elsevier, Amsterdam. 853 pp.

Martín-Piera, F. \& Lobo, J. M. 2003: Database records as a sampling effort surrogate to predict spatial distribution of insects in either poorly or unevenly surveyed areas. - Acta Ent. Iber. Macar. 1: 23-35.

Ribera, I. \& Vogler, A. P. 2004: Speciation of Iberian diving beetles in Pleistocene refugia (Coleoptera, Dytiscidae). - Mol. Ecol. 13(1): 179-193.

Rivas-Martínez, S. 1987: Memoria del Mapa de Series de Vegetación de España. Ministerio de Agricultura, Pesca y Alimentación, Madrid.

Rodríguez, T., Trigo, D. \& Díaz Cosín, D. 1997: Biogeographical zonation of the western Iberian Peninsula on the basis of the distribution of earthworm species. - J. Biogeogr. 24: 893-901.

Soberón, J. M. \& Llorente, J. B. 1993: The use of species accumulation functions for the prediction of species richness. - Conserv. Biol. 7(3): 480-488.

Soberón, J. M., Llorente, J. B. \& Oñate, L. 2000: The use of specimen-label databases for conservation purposes: an example using Mexican Papilionid and Pierid butterflies. - Biodivers. Conserv. 9: 1441-1466.

StatSoft. 2001: STATISTICA computer program, version 6.0. By StatSoft, Tulsa, OK.

Vigna Taglianti, A., Audisio, P. A., Belfiore, C., Biondi, M., Bologna, M. A., Carpaneto, G. M., De Biase, A., De Felici, S., Piatella, E., Racheli, T., Zapparoli, M. \& Zoia, S. 1992: Riflessione di gruppo sui corotipi fondamentali della fauna W-paleartica ed in particolare italiana. — Biogeographia 16: 159-179.

Williams, P. H. 1996: Mapping variations in the strength and breadth of biogeographic transition zones using species turnover. — Proc. R. Soc. Lond. B 263(1370): $579-588$. 